\title{
望裝前における鉄鋼の化学的表面処理について*
}

\section{Chemical Surface Preparation of Steel Prior to Painting}

H. E. Patterson**

\author{
Corrosion, Vol. 13, No. 1, 61t 68t (1957) Jan.
}

\section{序說}

塗装の方法は常により美しく，容易に，また耐食性の 良い皮膜が得られるよ5努力がなされてきている。乙か しどんな塗装法でもそれを塗るところの金属の表面につ いて注意を払わないと完全に応用することはできない。

一般に塗料の寿命を最大に保つために塗装前に取除い ておかなければならない表面の污れには三つの型があっ て,これら污れが完全に除かれているか否かは直ちに塗 料の保護力と金属表面の美観に影響するのである。

これら三つの型の污れとは (1) 油脂および成形, 圧 乙出し, 加工等に拈ける污れ，(2) 錆とスケール，(3) 顕 在的および潜在的な錆を誘発するるのとがある。

塗料を金属に密着させるためには，その表面が十分ぬ れることが必要である。油脂やその他の活れの存在は塗 料の湿潤作用を減少させ，塗膜が金属に密着するのを妨 害する。それゆえ油のある表面に塗装すると密着不良で 多くの場合皮をむくように塗膜ははげる。

金属表面に付く油脂には 2 種ある。すなわち鉱物性油 および動植物性の油である。鉱物性油はアルカリ，酸に 不溶で鹼化されない。この鉱物性油の除去は多くの場合 直接溶媒に溶すかまたは乳化する方法による。一方動植 物性油は酸, アルカリには同じく不溶であるが, アルカ リ洗浄液によって鹼化され除去できる。またこれは容易 に通常の溶媒に溶け，乳化して除くことができる。

スケールで包まれた鉄鋼もまた塗装においては問題が ある。このスケールは自身下にある鉄鋼をある程度保護 しているが, これが塗装に際していつもトラブルを起 乙，失敗の原因となる。これはスケールが船積み，工 作，建造中に割れを生ずるため，ここから下の金属に腐 食が進行するためである。塗装せる鋼の品物を露出し, 外気にさらしておくとスケールの部分が大きな斑点とな ってゆるくなり, あるいは浮上って塗膜は破壞し, はが れて錆は進行し，残った塗膜は下からえぐられる。

錆はスケールと同じ表面の活れに分類されるだろう。 錆の部分的除去は塗膜の寿命を短める。

3 番目に属する塗膜の寿命を損う表面の污れは潜在的 な錆を誘発する物質である。これらの物質はごく少量で その濃度以上に鋼の錆を早める。硫酸, 塩酸および人体

* 訳者 東京都立大学工学部工業化学科田島研究室 馬場宣良 ** American Chemical Paint Co. Ambler, Pennsylvania.
の汗に含まれるある種の有機酸の塩類は多くこの種類に 数えられ，これら潜在的な錆の誘発物は燐酸系の洗浄液 により錆とりと同時に効果的に中和することができる。

\section{洗淨の種類}

“化学的表面洗浄”なる語には金属の洗浄とその方法に ついて広い意味をもっている。処理する污れの種類およ び度合により表面処理は溶媒でふく場合もありまた苲気 脱脂アルカリあるいは水蒸気洗浄により完了し，あるい は錆またはスケール除きの前に油脂その他の污れを乳化 洗浄しなければならない場合もある。燐酸洗浄は軽い錆 取り, 特にワイヤブラシまたはサンドブラスト後に行 5 のに適している。スケールは硫酸または塩酸によるピッ クリングによらねばならない。

\section{1 溶媒洗淨}

溶媒でふくことは化学的洗浄法の中で最も効果は少な いが今日な抢広く使用せられている。この洗浄には非常 に多くの種類の溶媒が使用せられ，金属表面より機械的 に污れ，ごみ，油脂等を除く。溶媒としては鉱物油,ナ フサ, コールタール溶媒, アルコール, エーテル, アルコ ールとェーテルの化合物の混合物, 石油精製物, 八ロゲ ン化炭化水素等多くの物質が使用されている。普通ベン ソール, ガソリン, 四塩化炭素は有毒でかつ可燃性が強 いため用いられない。また溶媒洗浄は洗浄作用を効果的 に行うため厚い污れはあらかじめなんらかの方法で除い ておく。溶媒洗浄法は蒸気脱脂法を除きすべての場合間 もなく溶媒は除去した污れ，油等で污くなりその後は単 にこれらの物質が除去した表面に再沈着するにすぎな い。それゆえ効果的に洗浄を行うためには常にきれいな 溶媒を用いる必要があり, それがため大量の溶媒を必要 とする。

溶媒洗浄法は次のいずれかに分類される。（1）ふき洗 い，(2) 浸漬洗い，（3）吹付け法，（4）蒸気脱脂。

\section{ふき洗い}

ぼろ布，スポンシ，ブラシ等を溶媒に浸し金属の表面 をこする。過剩の溶媒执よび溶けてうすまった油は表面 の污れを除いて滴り落らなければならない。もし溶媒が 金属の表面で乾燥すると油脂は表面に薄い膜となって全 面に広がってしまうゆえ二度目にきれいな溶媒で洗浄す る。そうしないと残存する油脂の薄膜が塗料と金属との 間の密着性を妨害する。 


\section{㴖洗}

これは品物を溶媒の入った槽に浸漬して油脂を除去す るもので溶媒は間もなく污れてきて溶媒とともに油脂が 品物の表面に付くようになる。通常二つあるいはそれ以 上の棤に分けて使用し，污れた溶媒は予備洗浄に使 用 する。

\section{吹付け法}

溶媒を圧力を加えて品物の上に吹付ける。溶媒が品物 激突して脱脂が行われ溶媒は滴り落ちてタンク，貯蔵 槽にたまり再び吹付けに使われる。一度污れた溶媒を使 用するときには清潔な表面が保たれるよう注意が必要で ある。

\section{絜気脫脂}

第四番の脱脂が蒸気脱脂法である。品物は銁，棚ある いは籠等に入れられて溶媒の入っているタンクに吊され る。溶媒は熱せられ，その蒸気が冷い金属の表面に凝縮 して純粋な溶媒となり油脂，その他の污れを洗い去る。 この漸新的で最も理想的な蒸気脱脂法は装置の中の蒸気 層に品物が入ると品物のあらゆる面で溶媒蒸気が凝縮し 洗浄が行われるばかりでなく，蒸気の温度で熱せられ蒸 気層を出るときは速に乾燥されてしまう。

蒸気脱脂装置には通常溶媒の蒸留装置が付属して打り そこで污れた溶媒は精製され再び使用される。溶媒洗浄 法の利点は次のとおりである。

(1)：溶媒が速かに油脂を除くこと。(2)容易に用いられ ること。(3) 装置の床面積が小さくて済むこと。

欠点としては（1）溶媒抢よびその装置は間もなく油 脂で污されて脱脂能力は減退し，単に油脂を広げるのみ になること。(2) あし污された溶媒を捨てるとコストが 高くなること。(3) 蒸気脱脂法を除いて火災の危険があ ること。（4）油脂のみが除去せられ，錆，発銹性物䐝， 石簽類は除けない。(5) 発生する蒸気は多くの場合有毒 である。(6) ある種のクロールを含む溶媒は水や金属と 接触して加熱されると容易に分解して塩酸を生ずる。乙 かし大部分の蒸気脱脂用溶媒はいかなる酸が生じても中 和し安定化される。溶媒洗浄法は普通きわめて費用のか かる操作であり，清潔な表面を得るには高価な溶媒を大 量に使用しなければならない。「溶媒洗浄法のコスト」は 溶媒の種類と作業の形態によって違らがおよそ $100 \mathrm{ft}^{2}$ 当り 20 セント〜 1 ドルの間にある。

\section{2 アルカリ脫脂}

アルカリ脱脂は溶媒法より効果的でコストも低く毒性 も少ない。この方法には槽に浸すもの, 圧力を加えて吹付 けるもの，あるいは電解による脱脂法がある。アルカリ 洗浄剂は水に溶して用い高温度で作業する。これらは油 脂を噞化し，界面活性を示す成分がその他の污れを洗い 去るものである。污れは溶解作用よりむしろ液の清浄作
用あるいは簽化作用で除かれ，溶媒で直接洗われるので はなく污れと溶液が置き換って除かれるのである。アル カリ洗浄剤として今日用いられているものはアルカリ性

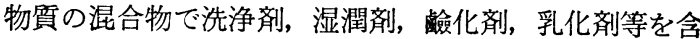
有する。洗浄剂としては第三燐酸ソーダ，ピロ燐酸ソー ダ, ソーダ灰, 苛性ソーダ, メタ珪酸ソーダおよびオル ソ珪酸ソーダ等がある。

\section{槛浸清法}

この方式は品物を温いアルカリ溶液に浸漬するのであ って，このとき溶液を㩭汼することが大切である。普通 は溶液を沸騰させて目的を達することができるが，また しばしば空気䚓捧をる併用する必要がある。この攪捧に よって摩擦が起きて污れは洗い去られる。溶液濃度は普 通 4 から 8 オンス/gallon, 温度 $180^{\circ} \mathrm{F}$ から沸点まで用 いられ高温度ほど能率が良い。

\section{吹付け法}

これは污れた品物にアルカリ洗浄液を機械的方法によ り吹付ける。温められた槽より熱溶液をポンプで吸みノ ズルから吹出して品物に当て, 洗浄の終った液は再び回 収される。溶液濃度は浸漬法に比してきわめて低く 0.1 から 2 オンス /gallon であり $160 \sim 200^{\circ} \mathrm{F}$ で作業する。

\section{露解洗淨}

本法は浸漬法とほぼ同じである。ここでは電解により 発生する多量のガスが污れた表面を機械的に攪找して効 果を発する。そのため溶液の電導度が高い必要があり， これがため電解脱脂には通常過㮃の苛性ソーダが含まれ て扣り, 高濃度, 高温度で作業する。濃度としては 6〜 14 オンス/gallon, 温度は $180 \sim 210^{\circ} \mathrm{F}$ が良く用いられ る。

アルカリ洗浄を行った金属を塗装するときは完全な水 洗が大切である。るしアルカリが残存すると染膜と反応 して石䖒を生じ密着性を悪くする。できれば処理した品 物は最後に酸性の液で洗うべきである。この酸洗いには 希薄なクロム酸，またはこれと燐酸との混合液が用いら れ，これで表面のアルカリは完全に中和されてのちにク ロム酸の薄い皮膜が残りすぐれた腐食抑制作用を示す。 このよう酸洗いは塗膜の寿命をきわめて長くするので ある。

アルカリ洗浄の特徴はその作用が急速に現われ非常に 能率良く油脂を除くことができてしか子経済的であり， かつ無毒である。これらのコストは洗浄剤の種類, 洗浄 法，あるいは表面の污れの度合によって異なるが $100 \mathrm{ft}^{2}$ 当り拉よそ $1 / 2$ 〜 10 セント位の範囲である。

アルカリ洗浄の大きな欠点は表面にアルカリが残存す ると塗料がはげ易くなることであるが，これは希酸で処 理することにより完全に防止できる。

\section{3 乳化溶都洗淨}


乳化溶媒法は厚い油脂, 防錆荗, 蠟等の除去に最も有 効である。溶剤は油を溶かし，油と溶剤はともにす寸ぎ 洗いで除去寸る。乳化溶剂は 4〜10 倍のケロシン, 鉱油 あるいは他の石油系溶剤でうすめ, 洗浄する品物は普通 1〜 5min この中に浸し，この間に溶媒は表面の污れを 浮上らせ溶解しているので，その後圧力をかけたスプレ イで洗浄する。この洗浄で浮上った污れが効果的に取去 られ洗浄が達成される。この方法の最大の利点は厚く付 着した油脂が能率良く除けることである。欠点は一つは 用いる溶媒の中には引火点が低く火災の危険が多いこと である。しかし最近は引火点の高い溶媒が研究されて火 災の危険も少なくなった。もう一つの欠点はコストであ る。コストは使用する溶媒と使用法にもよるが，大体 $100 \mathrm{ft}^{2}$ 当り $1 / 2$ セント〜 1 ドルの範囲である。

\section{4 水荥気洗淨}

水蒸気洗浄法は大さ, 形, 位置等により品物を浸漬し たりスプレイすることが不可能なときに用いられる。水 蒸気洗浄は蒸気と水だけでは行えず, 種々の洗浄剤が蒸 気と水の中に混ってはじめて効果的に塗装すべき表面を 清浄にする。水蒸気洗浄法のコストは $100 \mathrm{ft}^{2}$ 当り 20 セント〜 1 ドルの範囲である。

\section{5 酸洗淨}

酸洗浄はここ数年来完全に試験された新しい金属洗浄 法である。主要なる成分は燐酸であって,これに溶媒, 湿 潤剂または洗浄剂を加えて污れの除去を助ける。この酸 洗浄は能率良く油脂执よび污れを除き得てまた，潜在的 な錆を誘発する物質をも除去しあるいは中和する。また アルカリ洗浄と違って薄い錆から厚い錆に至るまで除去 して金属表面を細かく、ッチし，塗料の密着を良くす る。この酸洗浄法の効力は次の二つの主要な化学反応の ためである。（1）表面の污れの除去（2）金属表面に残 存する燐酸が不溶性の燐酸鉄皮膜を生ずることである。 この薄い皮膜がその後の塗装の良好な下地となり,さら に塗膜の下で広がる内部腐食を防止する。

酸洗浄にはブラシ, 浸漬, スプレイ法のいずれも適用 できる。基本の洗浄剤は使用法によって燐酸の濃度, 溶 媒扎よび湿潤剤の選択を異にする。ブラシで洗う方法に は2 種あって洗い落し法と拭い落し法とある。洗い落し 法はその名の通り金属の表面をブラシでこすり，その後 ホースの水で洗う。拭い落し法はブラシあるいはぼろで 金属の表面をふいてから次にぬれた清潔な布でふく。こ の布はたびたびきれいな水で洗って良くしぼり清潔に保 っておく。

酸の濃度は錆の程度によって定める。たとえば軽度の 錆は 1 容の酸に 5 容の水を混合するが厚い錆は 1 容の酸 に 1 あるいは 2 容の水を加える。うすめた洗浄風は金属 の表面にたっぷりと含ませ，十分にブラシでこする。必
要あれば錆がとれるまで何度む繰返す。次に表面をホー スの水で完全に洗 か, 清潔な湿った布でふき取り，表 面が乾いたらできるだけ早く塗装することが必要であ る。

酸洗浄法としては浸漬法が最も広く用いられる。品物 ははじめ温いあるいは冷い溶液に浸漬され, 次に水洗さ れてのち温いあるい兲いクロム酸溶液に浸されて乾燥 後塗装される。酸洗浄浴は室温から $180^{\circ} \mathrm{F}$ まで使用さ れ濃度は 20〜 50\% 容量濃度のものが使用される。普通 濃度と温度は浸漬時間が $10 \mathrm{~min}$ あるいはそれ以下にな るように調整されるが，もし錆あるいはスケールが高 濃度, 高温度の浴を用いて $10 〜 20 \mathrm{~min}$ 以上かかっても. 除かれないときは塩酸あるいは硫酸を使用した方が良 い。もし塩酸あるいは硫酸を用いた場合水洗が必要であ. り, 次に品物は燐酸洗浄液に浸漬して後に述べる腐食を 誘発する硫酸塩执よび塩化物を除去し清潔な不㗢態の金: 属表面を得る。酸洗浄の利点は次の 3 種の污れをすべて 除き得ることである。

（1）油脂, ごみ等 （2）錆とスケール （3）顕在的お: よび潜在的発錆性物質

さらに酸洗浄剤の残存は塗料の密着性を助け有益であ. る。欠点は浸漬槽あるいは吹付け装置が耐酸性の必要が. あることと成果が作業の熟練さと注意深さに直接影響な 受けることである。酸洗浄のコストは作業方法と表面の 污れにより非常に異なるが，ブラシでこする; 法は作業 中の不可避なロスがあるため $100 \mathrm{ft}^{2}$ 当り $40 〜 80$ セン トであり浸漬法は同じく1〜50セント位である。

\section{ピックリング}

塗装前に完全な表面を得るにはあらゆる錆とスケール を除くことが大切である。これはピックリングにより達 成できる。金属工業界では酸溶液に浸漬して除去してい る。この酸には種々のものが使用されているが硫酸, 塩 酸, 燐酸, 硝酸, 弗酸あるいは上記の混合物が使用され る。一般に硫酸が最も安価で沸点が高く能率も良いので 広く使用されている。ピックリングは普通浴に品物を沈 めるのであるが, あるものは吹付けたりあるいは品物の 上に流したりまた鋼の帯のようなるのは浴の中を連続的 に動かして作業する。ロール, 線引き, 焼鈍等の工程の 前では鉄またはその合金は開放された炖で熱せられて酸 化し, 冷却するとこの酸化物は固くてもろいスケールと なって付着する。このスケールはもろくて鉄より膨脹係 数が小さいので冷却するとひびが入る。

スケールの組成はまた均一でなく層によって酸素の含 有量を異にする 4 層よりなり, 最外部は通常最も酸素に 富みほぼ $\mathrm{Fe}_{2} \mathrm{O}_{3}$ の分子式に相当する $30 \%$ の酸素を含む。 その下は嵩が多くスケールの大部分を占め $\mathrm{Fe}_{3} \mathrm{O}_{4}$ に相 当する $28 \%$ の酸素を含む。次の層はほぼ $\mathrm{FeO}$ なる式 
に相当する $22 \%$ の酸素を含有し, 最も下の層は酸化物 と金属との混合物で酸素の含有量はさらに低い。

最外部の層は酸素含有量が高くピックリングの溶液に はほとんど溶けない。それゆえしばしばスケールの割れ 目から内部に酸が侵入して，スケールの内部や金属を侵 すことがある。鉄の含有量が高く酸素の少ない層は最外 層より酸に溶け易：反応が速いので内部層は早く溶け去 って，スケールの外観は破片状になってくずれ去る。金 属も酸と反応して水素を発生しスケールはるくれ上るよ らになる。

もしスケールが皆同時にとれて金属は直ぐにピックリ ング槽から引上げられるなら抑制剤の必要はないのであ るが，一部のスケールがまだ固く固着しているのに他の 部分は既にゆるくなりあるいはとれてしまうとこの部分 の地金が侵される。こうして酸が金属面を侵すとピット となり，全面のスケールが取れるまで酸と金属とが浪費 される。この浪費を防ぐのが後述の抑制剂である。

酸はまた他の付着物, 石灰, 錆, 执よびメッキ層等も 除去するのにも用いられる。表面の污れのなかでは錆が 最も容易に酸によって除去し得る。錆は金属の酸化物の 水和物であって, 硫酸, 塩酸, 燐酸にはスケールより容 易に溶けるゆえ，これらは酸で浮上るとい5よりむしろ “完全に溶解するのである。

錆はスケールと異なり常に成長する。これを除去しま た生成する原因を化学的に防止しなければ輤は塗料, 油，または蠟があってもその下で限りなく進行する。

ピックリングは次のさうな段階に分かれる。

(1) 金属の洗净処理 (2) ピックリング (3) 後処理 まず(1)と(3)の段階につき詳述する。

\section{洗 浮}

洗浄の目的は金属表面に固着して酸と金属の接触を妨 げ゙る污れを完全に除くにある。油脂類の污れが最も普通 であって前に述べた各種の方法が応用できるが, 通常ア ルカリ浸漬が比較的安価で行い易いのでよく用いられ る。

処理後は完全に水洗を行いアルカリが残留して酸を中 :和し浪費しないようにする。

\section{ピックリングした金尿の後処理}

ピックリングした後, 品物は冷水で十分洗浄し酸や酸 泣金寓との反応生成物が薄い膜となって付着しないよう 注意が必要である。燐酸以外の酸および塩類は锖を促進 するので執燥する前に十分除いておかなければならな い。水洗は敏速に行うべきで持に酸の温度が高いときに は注意を要する。これは酸つ塩類が執燥すると水洗が難 功々れ以後の操作に支障をきたすからである。

ピックリングに用いた酸あるいは塩が除かれると金属 红適宜次のような処理が行われる。最初は錆の防止と塗
装の準備である。冷水洗净後炭酸ソーダまたは第三燐酸 ソーダ 1/4〜1/2 オンス/gallon の弱アルカリ溶液で沸 騰し錆を防止する。アルカリ性になった金属の表面は錆 は速かには発生しないが長期間空中に放置するときは表 面に油を塗っておくべきである。こうした処理をしたも のは塗装はできなくなる。アルカリ性の表面に塗装する と湿気のある大気中では良く密着せずはがれ易い。これ は残存するアルカリと湿気が電解液となって皮膜の下で 腐食が起るためである。染装された表面はわずかに酸性 であるのが理想的で $\mathrm{pH}$ 3〜5 のあたりが良い。燐酸ま たはクロム酸は塗装に適する酸性洗浄液である。この二 つの酸は表面を保護し不働態にするが硫酸あるいは塩酸 は残留すると錆を誘発するので用いられない。最近は塗 装法が発達してきて表面が中性あるいは弱アルカリ性の とき最良の結果が得られるようになったことは注目に值 する。

\section{使用する酸}

前に述べたごとくピックリングには塩酸, 硫酸, 硝酸, 燐酸および弗酸等が用いられるが中でも塩酸と硫酸がコ スト, 取扱い法, 容易さおよび速度の点から賞用され る。濃硫酸は鋼を侵食しないばかりかスケールをる除か ない。

普通うすめて使う。硫酸は等量の水でうすめられるま では軟鋼を著しく侵さない。一定温度に拈ける硫酸の侵 食速度は酸濃度が $39 \%$ 容量濃度までは急速に増加する。 それからは酸濃度の増加とともに漸減し $50 \%$ 位で酸の 作用は停止して鋼を侵さなくなる。ゆえに硫酸は 1 39 \%の範囲で使用せられ，2〜20\% が最も普通である。こ れは作業時間が適当になるよう選定する。

塩酸は硫酸と違。て侵食速度は市販の濃塩酸 $20^{\circ} \mathrm{Bé}$ に至るまで単調に増加する。酸溶液の活性は通常のピッ クリングでは酸の濃度に比例し，また温度に著しく影響 を受ける。 $140^{\circ} \mathrm{F}$ の硫酸溶液は $100^{\circ} \mathrm{F}$ の溶液より約 40 倍も強力で $180^{\circ} \mathrm{F}$ では 1300 倍, $225^{\circ} \mathrm{F}$ では 4000 倍 にもなる。

硫酸によるピックリングに挍いては酸は金属およびス ケールと反応して硫酸第一鉄を生成する。この硫酸第一 鉄の存在はピックリングに多大の影響を与えるのであっ て硫酸第一鉄が増加すると浴の作用は緩慢になりスケー ルを除くためには長い時間が必要になる。硫酸第一鉄が 増すと酸の活性は著しく減少するがこれを回復するため に新に硫酸を追加することは経済的ではない。約 2.5 lb/gallon の硫酸第一鉄が存在したならば酸の追加をと めて温度を上げ同じ浸漬時間を保つがよい。徐々に温度 を上げることにより同じピックリングの時間が保持でき て新しい酸が節約されコストの低減になる。もう一つピ ックリングに大きな影響を与えるすのは攪䢁である。一 
定濃度と温度では浴の侵食力は攪䢁すると強くなる。金 属の表面にある酸は金属を溶解して硫酸第一鉄に富み酸 の活性が弱くなるのでスケールの除去が遅くなるが，鄮 挥すると常に新しい酸が金属の表面に運ばれて硫酸第一 鉄に富む液は拡散しその結果 スケールの脱離が早くな る。覧找は普通浴を加熱している水蒸気を利用する。蒸 気は底部にある鉛管の孔またはインジェクター型ノズル より吹出す。

濃度，温度，硫酸第一鉄および攪挥の影響を考える と, 最も妥当な作業条件が存在する。新しい浴は硫酸第 一鉄が存在しないで比較的低温度で濃度も2 20\%で 所定の時間にピックリングを行うことができる。硫酸第 一鉄が増加してくるとピックリングの速度が遅くなるの で酸の濃度を増すかまたは温度を上げるかして反応速度 を増さなければならない。両方法とも用いられている が，普通は装置の温度を上げるために蒸気を用いるので 浴の睍拌も増加する。最良の方法は酸濃度を一定にして おいて硫酸第一鉄による侵食速度の減退を温度によって 調節することである。浴中に硫酸第一鉄が $2.5 \mathrm{lb} / \mathrm{gallon}$ 以上溶解するとスケールの除去作用が非常に弱くなるこ とが知られているのでこの点で酸の追加を中止し, 残っ た浴はできるだけ使って最後に捨てる。酸が弱くなって 硫西第一鉄が増した浴は浴温を徐々に上げて速度を調節 しながら最後には沸点までもっていきピックリングを行 う。そうしてあとは捨てる。このようにすれば酸の濃度 が非常に減るまで利用できて消費する酸を節約できる。

\section{ピックリンクの抑制旅}

抑制剤のないピックリング浴は損失が多い。スケール を除くためには酸はある程度下の地金を溶かさな情れば ならないか，抑制阂のない浴はスケールが除かれたのち も金属を溶かし，全部のスケールがとれたときには鋼は 過度に侵されている。しかも金属が浪費されるのみなら ず酸もむだに使われるのでこの二つの損失を抑制剂によ って防止する。抑制剂はピックリングにおける酸の作用 を局限し下地金属が過度に侵されないようにする。一定 面積当りの金属が抑制剤を加えた浴で侵される割合を無 添加の浴と比較すると次のようである。無添加の浴の一

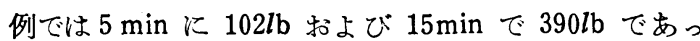

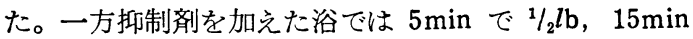
で $2 l \mathrm{~b}$ および $30 \mathrm{~min} て ゙ 5 l \mathrm{~b}$ であった。上記の資料はす ベて $10 \%$ 硫酸で温度 $200^{\circ} \mathrm{F}$ で実験したものである。

金属が酸に溶けるときは一定量の水素が発生する。発 生した水素ガスは単原子よりなり，これは速かに二分子 結合して分子状あるいは気体水素となる。ピックリング 溶液中で金属の表面に発生した水素はきわめて軽く，抑 制剂のない浴では多数の気泡が発生する。これが水面に
達すると破裂して酸を激しく空中にまき散し，望息性の ヒュームが空中に浮遊して作業者を害し, 作業場の金属 や建物の石積みを急速に腐食する。昔の作業者達にとっ てはこの泡立ちが「浴は缏いている」という目安になっ ていた。抑制昘は水素の発生を少なくしてこのヒューム を最小にとどめる。また抑制凧の発泡性は酸スプレイの 場合を除いて浴の表面を覆い熱が放散するのを最も少な くする。抑制斉を用いることによって酸も金属も節約に なるということはしばしば見逃されている間接的な利益 の一つであるが，直接の利益としては (1) 浴の寿命が 長くなり浴を作り換える手数が省ける。(2) 同じ量の酸 で多量の金属がピックリングできる。(3) 酸のヒニーム が最小になる。(4) 建物と装置の腐食が少なくなる。あ る場合には硫酸によるピックリングより燐酝によった方 が良いことがある。槽の数は硫酸ピックリングの場合水 洗を完全にするため多数必要となる。燐酉、は普通の状態 では硫酸ほど腐食性がなく設備費が安く保守が容易であ る。作業者に嫌われる不快なヒュームや腐食性のヒュー ムも発生しない。昔は燐酸が硫酸に比して高佂だったの であまり用いられなかったが，しかし最近の新しい方法 では燐酸によるピックリングが良いといわれておりコス トの点も他の酸と同じ位になりつつある。燐酸ピックリ ングは残留物が錆を誘発せず，容易に洗い流すことがで きるので燐酸皮膜処理の前処理に適している。またこの 場合燐酸と硫酸とを併用することも推奖されている。硫 酸は鎍とスケールを除き，燐酸は硫酸を洗い流して錆を 誘発する物䆓を中和する。燐酸はまた金属の上に薄い燐 酸皮膜を残して塗装の良い下地となる。

\section{総括}

金属表面についている油脂, 蠟およびスケールのごと き污れと顕在的および潜在的な錆を誘発する物質につい ての完全なる除去法につき述べた。ピックリングによっ て金属面は粗くエッチされ，塗装に際し機械的接着を助 けている。このような接着法は使用条件が穏かで塗膜の. 寿命もあまり長くなくても良いときに有用である。

\section{燐酸皮膜}

もし大気の条件が苛酷で塗膜の寿命も長いことが要求 されるときは, 塗装する表面を化学処理して塗膜と化学 結合するような処理をする。このような処理をして塗膜 の寿命を何倍かに延すには多くの処理段階が必要であ， る。鉄堸に行 万基本的な過程は表面を不溶性燐酸塩に変 えることである。この燐酸皮膜法は次の四つの理由によ って塗膜の寿命を非常に長くする。(1) 塗料の密着性を 改善する (2) 非伝導性の結晶性不活性皮膜が塗膜と金 属とを絶縁して電気化学的腐食を防止する。(3) 塗膜の きずから腐食の侵入が少ないこと。(4) 少量の塗料で長 い寿命が得られること。これらの皮膜は厚い, 肉眼的な結 
晶性のるのから平滑で硬く微結晶性のものまである。燐 酸皮膜は基体金属とは良く密着しており，熱膨脹や機械 的变形に対しては十分なる強度と柔軟性を持っている。

燐酸皮膜には二つの基本形がある。すなわち鉄の燐酸 塩と亜鉛の燐酸塩である。二つのうち亜鉛の燐酸皮膜は 一般に広く使用せられて良い結果を示している。亜鉛の 燐酸塩は比較的厚く $60 \sim 4000 \mathrm{mg} / \mathrm{ft}^{2}$ の範囲にわたって 結晶性の皮膜が得られる。塗装の前処理としては 150か ら $400 \mathrm{mg} / \mathrm{ft}^{2}$ の皮膜が適当である。むつと厚い皮膜は るろく，塗装すると耐衝撃性および機械的強度が劣化す る。厚い皮膜はまた結晶構造が粗くなり多くの塗料を吸 収する。燐酸鉄の皮膜は前者より薄くて硬く微結晶性構 造である。これは 40〜90mg/ft の薄い層なので塗料の 吸収が少なく少量の塗料で光沢ある仕上げができる。

亜鉛の燐酸皮膜は亜鉛の燐酸塩を飽和または過飽和さ せた燐酸溶液で処理する。遊離の燐酸は金属表面で反応 するので少量は消費される。この金属表面において酸が 消費されると溶液の燐酸亜鉛の溶解度は低下乙て金属の 表面に析出する。硫酸塩, 亜硝酸塩, 塩素酸塩, 過酸化 物のような促進剤は添加すると皮膜の生成速度を早め る。それらはまた別の大切な作用があり，溶液に第一鉄 塩が生じないようにする働きをもつ。遊離の燐酸が金属 と反応すると，ある量の鉄は溶けて燐酸第一鉄となり入 り込む。このためピックリングの液と同様, 鉄は徐々に 皮膜の生成速度が低下し，同時にできた皮膜の性質が劣 化する。こうなったら液を捨てて入れ 換える必要があ る。しかし促進剤の添加により第一鉄の生成を防止し浴 の寿命を高め得る。過剩の鉄は第二鉄塩として沈殿し， これは白色の泥となってタンクの底に沈む。工程は普通 次の 5 から 7 段階である。

(1)洗浄：適当な洗浄法により金属の表面から油脂を除く。

(2)水洗：表面に残存する洗浄液を洗い流すこと。

(3)ピックリング : 錆とスケールを除くこと。

(4)水洗 : 次の工程に移る前に十分水洗し微量の酸も残存 せぬこと。

（3）および( 4 )の工程は品物の表面に錆またはスケー ルがなければ省略するが洗浄後二度の水洗が望ましい。

\section{(5)燐酸皮膜処理}

(6)水洗 : 過㮃の燐酸処理液を洗い落す。

(7)酸性水洗：クロム酸，あるいはクロム酸と燐酸混合液 で処理して皮膜の表面を不働態化し水洗で残存するア ルカリ塩を中和する。この水洗により表面は微酸性に 保たれ，塗膜の寿命が最大になる。

(8)乾燥してできるだけ速かに塗装。

\section{1. 洨清法}

浸漬法は最も古くから用いられ，また広く用いられて いる方法である。品物は 3〜10\% 容量濃度の溶液を
$160 \sim 210^{\circ} \mathrm{F}$ に保った中に浸漬される。塗料が固着す る皮膜の重量は $150 \sim 400 \mathrm{mg} / \mathrm{ft}^{2}$ の範囲であって，2〜 $5 \mathrm{~min}$ で生成される。

\section{2. 吹付け法}

吹付け法は最近発達したもので，広く工業的に成功し ている方法である。溶液は貯蔵槽から吸い上げられノズ ルから品物に吹付けられて再び貯蔵槽に戾る。溶液の濃 度は一般に浸漬法より低く普通 2\% 位であって 110〜 $160^{\circ} \mathrm{F}$ で用いられる。吹付け法は塗料が固着する皮膜 の重量が $150 〜 400 \mathrm{mg} / \mathrm{ft}^{2}$ 位のときのみ用いられる。

\section{3. ブラシ法}

ブラシ法は大きさ，設置場所また部品の数等の関係で 浸漬または吹付け法が経済的でないときに用いられ，燐 酸処理の薬品は 1 から 4 倍の水に溶汃し室温で使用す る。希釈の比率は温度と時間によって調節される。普通 1 から $10 \mathrm{~min}$ の時間で $60 \sim 150 \mathrm{mg} / \mathrm{ft}^{2}$ の皮膜が得られる。

液はブラシ, スポンジ, ぼろ布, あるいはスプレイガ ンを用いたり他の可搬性の装置を使用して塗布する。

以上述べたことは主として鉄鋼に対する処理 法であ る。しかし他の金属，亜鉛，メッキした鉄，アルミニウ ムのようなものについても基本的には同じ方法でよい。 ただ亜鉛とアルミニウムのピックリングには特別な処理 が必要なのでこれについてはここではふれない。今日金 属加工業界において重要なるのになった燐酸皮膜の特徴 について繰返してあげれば，特徴としては，(1) 塗膜の 密着性を良くする。(2) 不活性な結晶性皮膜ができて皮 膜と金属の間を絶縁し，電気化学的腐食を防止する。(3) 塗膜のきずから侵入する腐食がきわめて少ないこと。

(4) 少量の塗料で長い寿命が保てること。

上記の特徴は燐酸皮膜の密着性が良く, 不活性で電気 絶縁性があるためである。皮膜は鉄鋼表面の必須の部分 を形成し，実際には鉄鋼の表面の一部分が皮膜に変化す るのである。

欠点は (1) 装置を多く必要とする。(2) 処理段階が 多くなるため他の化学処理よりコストが高くなることで ある。燐酸法のコストは吹付け法では通常 3.5〜8 セン ト100ft ${ }^{2}$ であり，浸漬法では 5〜15 セント/ $/ \mathrm{ft}^{2}$ であ る。ブラシ法のゴスト 50 セントから 1 ドルの範囲で あるがこれは一度使った薬品は回収して再び使用するこ とが不可能なためである。

塗装前に良好で完全な前処理を行うことにより，工業 界では年に数百万ドルの利益となる。ときにははじめは コストが高くても終りにはかえって安くなることがあ り，これは単に塗料の寿命が延びたことによるだけでな く保守費や維持費が減少することによるのである。 本文に対する質疑は 1957 年 6 月の本誌に掲載の予定 である。 